\title{
IS THE CURE WORSE THAN THE PROBLEM ITSELF? IMMEDIATE LABOR MARKET EFFECTS OF COVID-19 CASE RATES AND SCHOOL CLOSURES IN THE U.S.
}

\author{
Felipe Lozano Rojas \\ Xuan Jiang \\ Laura Montenovo \\ Kosali I. Simon \\ Bruce A. Weinberg \\ Coady Wing \\ Working Paper 27127 \\ http://www.nber.org/papers/w27127 \\ NATIONAL BUREAU OF ECONOMIC RESEARCH \\ 1050 Massachusetts Avenue \\ Cambridge, MA 02138 \\ May 2020
}

Bruce Weinberg gratefully acknowledges support from UL1 TR002733. The views expressed herein are those of the authors and do not necessarily reflect the views of the National Bureau of Economic Research.

NBER working papers are circulated for discussion and comment purposes. They have not been peer-reviewed or been subject to the review by the NBER Board of Directors that accompanies official NBER publications.

(C) 2020 by Felipe Lozano Rojas, Xuan Jiang, Laura Montenovo, Kosali I. Simon, Bruce A. Weinberg, and Coady Wing. All rights reserved. Short sections of text, not to exceed two paragraphs, may be quoted without explicit permission provided that full credit, including (C) notice, is given to the source. 
Is the Cure Worse than the Problem Itself? Immediate Labor Market Effects of COVID-19 Case Rates and School Closures in the U.S.

Felipe Lozano Rojas, Xuan Jiang, Laura Montenovo, Kosali I. Simon, Bruce A. Weinberg, and Coady Wing

NBER Working Paper No. 27127

May 2020

JEL No. I1,J2,J6

\section{$\underline{\text { ABSTRACT }}$}

The relationship between population health and measures of economic well-being and economic activity is a long standing topic in health economics (Preston, 1975; Cutler, Deaton, and LlerasMuney, 2006; Ruhm, 2000). The conceptual issues in analyzing the complicated link between health and economic well-being are central to understanding the implications of the COVID-19 epidemic in the United States The public health shock of the epidemic has direct economic impacts, but the mitigation policies governments are using to control the spread of the virus may also damage economic activity. We estimate how state job market conditions respond to state COVID-19 infections and school closures, which are the earliest of the major mitigation policies. Mitigation policies and local epidemiological conditions explain some of the variation in unemployment patterns. However, the historically unprecedented increase in new UI claims during the weeks of March 15-21 and March 22-28 was largely across-the-board and occurred in all states. This suggests most of the economic disruption was driven by the health shock itself. Put differently, it appears that the labor market slowdown was due primarily to a nationwide response to evolving epidemiological conditions and that individual state policies and own epidemiologic situations have had a comparatively modest effect.

Felipe Lozano Rojas

School of Public \& Environmental Affairs Indiana University

2451 E. 10th Street

Bloomington, IN 47408

flozanor@indiana.edu

Xuan Jiang

Department of Economics

The Ohio State University

1945 N High St

Columbus, $\mathrm{OH} 43210$

United States

jiang.445@osu.edu

Laura Montenovo

O'Neill School of Public and

Environmental Affairs

Indiana University

2451 E. 10th Street

Bloomington, IN 47408

lmonten@iu.edu

\author{
Kosali I. Simon \\ O'Neill School of Public and \\ Environmental Affairs \\ Indiana University \\ 1315 East Tenth Street \\ Bloomington, IN 47405-1701 \\ and NBER \\ simonkos@indiana.edu \\ Bruce A. Weinberg \\ Department of Economics \\ Ohio State University \\ 410 Arps Hall \\ 1945 North High Street \\ Columbus, $\mathrm{OH} 43210$ \\ and NBER \\ weinberg.27@osu.edu \\ CoadyWing \\ Indiana University \\ 1315 E 10th St \\ Bloomington, IN 47401 \\ cwing@indiana.edu
}




\section{Introduction}

The coronavirus epidemic has caused more than 190,000 deaths around the world, and at least 50,000 deaths in the United States as of this writing. During the first few months of 2020, government and private efforts to prevent the spread of the virus reshaped daily life in the United States. Schools and businesses closed on a massive scale, and states issued shelter in place orders requiring people to stay home. As the epidemic continues, it will be crucial to balance the economic harms of these measures against their ability to reduce viral transmission. The relationship between population health and economic well-being and economic activity is a longstanding topic of interest in health economics. Previous work documents that stable relationships between population health and measures of wealth can be disrupted by large changes in epidemiological conditions, such as the HIVIAIDS epidemic in sub-Saharan Africa (Cutler, Deaton, and Lleras-Muney, 2006; Preston, 1975). There is also evidence that mortality and morbidity depend on macroeconomic conditions (Hollingsworth et al, 2019; Ruhm, 2000), and that both working conditions and involuntary unemployment affect health outcomes (Fletcher et al, 2011; Sullivan and Von Wachter, 2009). Evidence from historical epidemics and simulation models suggest social distancing can slow the spread of the virus (Chinazzi et al 2020; Fang et al 2020; Ferguson et al 2020; Bootsma and Ferguson, 2007; Ferguson et al 2006). To shed light on the relative effects of policies vs. private responses, this article examines the association between local unemployment insurance claims, epidemiological conditions, and the earliest form of local policy responses - school closures.

Given the decentralized structure of the American government, state policy makers have become critical actors and have exercised considerable discretion over the mitigation policies used to control the epidemic. Some observers and policy makers have suggested that the economic and health damages of the policy response may be worse than the epidemic itself (Bendavid and Bhattacharya 2020; Ioannidis 2020; Trump 2020). The third week of March 2020 saw a historically unprecedented spike in new claims for unemployment insurance (UI) (DOL 2020). UI claims have continued to grow since then, and some states are already considering weakening their mitigation policies to reduce job losses. Pressure to do so will rise in the coming weeks. However, it is unclear how much of the rise in unemployment was driven by shut-down policies. Even without government mandates, private decisions to avoid social interactions in response to the epidemic would have reduced demand for activities like retail, air travel, hotel rooms, and on-site restaurant meals. We provide early evidence that the bulk of the spike in UI claims seems to reflect the national and international COVID-19 crisis as opposed to local COVID-19 cases or local policy responses.

\section{Data and Methods}

We measure labor market activity using weekly new UI claims per covered worker in each U.S. state, including Washington DC, and Puerto Rico. (We use the number of covered workers in January 2020 as a fixed denominator.) Our measure of epidemiological conditions is confirmed COVID-19 cases per capita in each state-week (New York Times, 2020). We measure the intensity of state school closures by combining district and state level school closures data (Education Week 2020) with NCES data on school district enrollment to compute the fraction of school days missed by the average child in each state and week (NCES 2018). Table 1 shows descriptive statistics. Our data covers the period from the first week of 2020 to the week ending on March 28, 2020. Descriptive statistics for each week in March are in Table S.1.

School closures are one of the earliest mitigation policies (Gupta et al, 2020). They typically started at the district level before becoming a state-wide policy. They likely increase social distancing, but they also reduce consumer and labor demand in many markets, and they may make it hard for parents to remain productive in the workforce given childcare responsibilities. To unpack the role of policy and epidemiological conditions on UI claims, we regressed log UI claims on school closure rates, COVID-19 case rates, and state and time fixed effects. We fit a restricted model with a time-invariant slope on school closures and COVID-19 cases, and an unrestricted model that allows these effects to vary over time.

1) $\ln (y)_{s t}=\beta_{1} \cdot$ School Closures $_{s t}+\beta_{2} \cdot \ln \left(\right.$ COVID $\left._{s t}\right)+\gamma_{t}+\epsilon_{s t}$ 


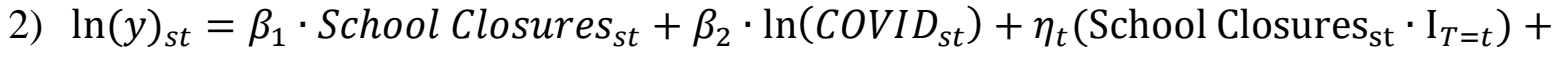
$\xi_{t}\left(\ln \left(\operatorname{COVID}_{s t}\right) \cdot \mathrm{I}_{T=t}\right)+\theta_{s}+\gamma_{t}+\epsilon_{s t}$

In these models, $y_{s t}$ represents new UI claims per 1,000 workers in week $t$ in state $s$. School Closures $s_{s t}$ represents the fraction of school days missed by the average child in each state and week (Education Week 2020; NCES 2018), and COVID $D_{s t}$ is the number of confirmed cases per capita. The fixed time effects capture shocks common to all labor markets in the U.S.

\section{Results}

In Figure 1 - Panel A, we separate the states into high, medium, and low COVID-19 case rates and link them to the UI claims (per 1,000 workers) over time. In the weeks leading up to March 15-21, the three groups of states had roughly 1.46 weekly claims per 1,000 workers. Then the UI claims rate spiked in all three groups. The states with higher rates of infection experienced a larger increase in new UI claims. Compared to the week ending on March $14^{\text {th }}$, by March $21^{\text {th }}$, UI claims grew by $1,281 \%$ in high COVID-19 states, and by $1,095 \%$ in low COVID-19 states. By March $28^{\text {th }}$, in low infection states there were 39.5 UI claims per 1,000 workers whereas in low infection states there were 34.5. Thus, the differences in the size of the spike in new UI claims are small compared to the overall change experienced by all states.

In Figure 1 - Panel B we divide the states into three groups based this time on the share of school days missed per child. Once again, the three groups had similar UI claim rates in the weeks leading up to March 15-21. The size of the spike by March $21^{\text {st }}$ in UI claims was larger in states with the most intensive school closures (1,704\% increase) compared to the intermediate group (1,047\% increase), and the lowest group (593\%). However, even the smallest response implies a record setting 6 -fold increase in UI claims in only one week. Thus, the data recording the immediate labor market response suggest that local school closures policy and local epidemiological conditions do matter, but they are secondary determinants of the deterioration in labor market outcomes so far.

Table 2 shows estimates from several versions of equations (1) and (2). These estimates are weighted by state population and exclude NY, which was an outlier. (See table S1 for results that include NY and table S2 for unweighted results.) Table 2 Column 1 only includes time dummies and does not adjust for school closures or COVID-19 cases. Columns 2-4 add School Closures, School Closures $\times$ time interactions, and state fixed effects. Columns 5-7 repeat the sequence with COVID-19 cases. Columns 8-10 include both School Closures and COVID-19 cases, with columns 8 and 10 showing the full specifications presented in (1) and (2). There are two main patterns. First, the school closures and the number of cases have low explanatory power relative to the time variables. Second, even if significant, the school closures and cases are not robust to model saturation. Because it emphasizes the common time effects rather than time varying slopes, the model in column 8 is our preferred specification.

Figure 2 plots the relationship between UI claims, time, local COVID-19 cases, and school closures using the time-invariant coefficients model shown in Table 2 - Column 8. The graph plots the natural logarithm of new UI claims per worker against COVID-19 cases per capita (Panel A), and against the share of school days missed per student (Panel B). Both panels show the fitted line holding other variables constant at the mean on the given date. The markers for each state are sized in proportion to their population in 2019. State UI claims are shown in orange for March 8-14, green for March 15-21, and black for the week of March 22-28.

Figure 2 - Panel A shows that when New York is excluded from the data, UI claims per 1,000 workers are higher in states with higher COVID-19 case rates. The regression model implies that - after adjusting for the time period effect and school closures - increasing a state's COVID-19 case rate from the nationwide average in March 8-14 (0.75 cases per 100,000 individuals) to the nationwide average in March 15-21 (6.5 cases per 100,000 individuals) would have increased the new UI claims rate by about $2.3 \%$ (SE 7.1\%). If the movement would have been from the baseline in March 8-14, all the way to the nationwide 
average in March 22-28 (29.9 cases per 100,000 individuals), the increase in new UI claims would have been 13.2\% (SE 6.1\%). However, controlling for state COVID-19 case rates explains very little of the large jump in claims associated with the week of March 15-21. In other words, the week effect is large relative to the COVID-19 gradient. Regression estimates including New York, shown in Figure S.1, are essentially flat because New York's new UI claims are considerably lower than one would expect based on its very high rate of COVID-19 cases.

Figure 2 - Panel B shows that the share of school days missed in a state is associated with more UI claims. The regression model implies that - after adjusting for the time period effect and state COVID-19 case rates - switching from no school closures in a week to all schools being closed for a week would increase the UI claims rate by $139.8 \%$ (SE 94\%), although these estimates are very imprecise. This change is small compared to the nationwide jump in UI claims for the week of March 15-21. Regression estimates imply that the new UI claims grew from the baseline in March 8-14 by 453.9\% (SE 190\%) in the average state even after adjusting for state school closures and COVID-19 case rates. Growth from the baseline in March 8-14, up to March 22-28 implied an increase of 828.8\% (SE 3.77\%).

The regression model provides a benchmark of expected unemployment rate in a state given national patterns and local conditions. Some states deviate substantially from what would be expected based on the model. For example, Hawaii, Pennsylvania, Kentucky, Michigan and Rhode Island have unemployment claims that are considerably higher than the model predictions. In contrast, South Dakota, Connecticut, Wyoming, Utah and Colorado have lower unemployment claims than predicted (see Table S.4).

\section{Discussion}

The COVID-19 epidemic has generated a huge and very sudden increase in unemployment claims in the United States. Our analysis decomposes the overall changes in employment into nationwide shocks and state level variation in local health conditions and early policy responses. The bulk of the spike in UI claims seems to reflect the national and international COVID-19 crisis as opposed to local COVID-19 cases or local policy responses. The estimates suggest that it is unlikely that states could have avoided the huge spike in job losses by avoiding early school closures. However, the data do suggest that both school closures and state level measures of the severity of the epidemic are also associated to some degree with more UI claims. This analysis may be relevant for state policy makers as they assess impacts of tightening or loosening of social distancing policy actions.

The results in this note are relevant to the health economics literature on population health and economic activity. They show that negative public health shocks can have enormous effects on labor markets that dwarf the effects of policies designed to mitigate the epidemic itself. It is not yet known whether the job losses occurred where the epidemic was expected to grow more rapidly or whether states took stronger closure actions when they expected more rapid expansion in the scale of the local epidemic. In interpreting our estimates, we emphasize that our short-term assessment is no substitute for later longterm analysis of responses. Even among short term measures, the April Current Population Survey will enable analyses of the incidence of unemployment across various groups. In addition, our analysis is not based on a randomized experiment so causal inferences should be made cautiously. Nevertheless, state policy makers face a series of choices in the immediate future, and our analysis may help inform those decisions and more broadly, the literature on population health and the economy. 


\section{References}

Bendavid, E. and Bhattacharya, J. (2020) "Is the Coronavirus as Deadly as They Say? Current estimates about the COVID-19 fatality rate may be too high by orders of magnitude" Wall Street Journal. March 24, 2020. Available: https://www.wsj.com/articles/is-the-coronavirus-as-deadly-as-they-say-11585088464

Bootsma, M., \& Ferguson, N. M. (2007) "The effect of public health measures on the 1918 influenza pandemic in US cities." Proceedings of the National Academy of Sciences, 104, No.18: 7588-7593.

Chinazzi, M., Davis, J. T., Ajelli, M., Gioannini, C., Litvinova, M., Merler, S., Pastore y Piontti, A., Mu, K., Rosi, L., Viboud, C., Xiong, X., Yu, H., Halloran, M.E., Lngini, I. M. \& Vespignani, A. (2020). "The effect of travel restrictions on the spread of the 2019 novel coronavirus (COVID-19) outbreak". Science, 3686489: 395-400.

Cutler, D., Deaton, A., \& Lleras-Muney, A. (2006). "The determinants of mortality". Journal of Economic Perspectives, 20(3), 97-120.

Fang, H., Wang, L., \& Yang, Y. (2020). "Human mobility restrictions and the spread of the novel coronavirus (2019-ncov) in China" NBER Working Paper 26906.

Ferguson NM, Laydon D, Nedjati-Gilani G, Imai N, Ainslie K, Baguelin M, Bhatia S, Boonyasiri A, Cucunubá Z, Cuomo-Dannenburg G, Dighe A (2020) Impact of non-pharmaceutical interventions (NPIs) to reduce COVID-19 mortality and healthcare demand. Imperial College COVID-19 Response Team, London, March, 16: URL https://www. imperial. ac. uk/media/imperialcollege/medicine/sph/ide/gida-fellowships/Imperial-College-COVID19-NPI-modelling-16-03-2020.pdf.

Ferguson, N. M., Cummings, D. A., Fraser, C., Cajka, J. C., Cooley, P. C., \& Burke, D. S. (2006). "Strategies for mitigating an influenza pandemic". Nature, 442(7101), 448-452.

Fletcher, J. M., Sindelar, J. L., \& Yamaguchi, S. (2011). Cumulative effects of job characteristics on health. Health economics, 20(5), 553-570.

Gupta, S.; Nguyen, T.; Lozano-Rojas, F.; Raman, S.; Lee, B.; Bento, A.; Simon, K.; Wing, C. (2020) "Tracking Public and Private Response To The Covid-19 Epidemic: Evidence From State and Local Government Actions" NBER Working Paper 27027.

Hollingsworth, A., Ruhm, C. J., \& Simon, K. (2017). "Macroeconomic conditions and opioid abuse". Journal of Health Economics, 56, 222-233.

Ioannidis, J. (2020) "A fiasco in the making? As the coronavirus pandemic takes hold, we are making decisions without reliable data". STAT. March 17, 2020. Available:

https://www.statnews.com/2020/03/17/a-fiasco-in-the-making-as-the-coronavirus-pandemic-takes-holdwe-are-making-decisions-without-reliable-datal

"Map: Coronavirus And School Closures," Education Week, 2020.

https://www.edweek.org/ew/section/multimedia/map-coronavirus-and-school-closures.html

National Center for Education Statistics. "Common Core of Data" Available:

https://nces.ed.gov/ccd/ccddata.asp

Preston, S. H. (1975). "The changing relation between mortality and level of economic development". Population studies, 29(2), 231-248.

Ruhm, C. J. (2000). "Are recessions good for your health?" The Quarterly Journal of Economics, 115(2), 617-650. 
Sullivan, D., \& Von Wachter, T. (2009). Job displacement and mortality: An analysis using administrative data. The Quarterly Journal of Economics, 124(3), 1265-1306.

Trump, D. (2020) "WE CANNOT LET THE CURE BE WORSE THAN THE PROBLEM ITSELF. AT THE END OF THE 15 DAY PERIOD, WE WILL MAKE A DECISION AS TO WHICH WAY WE WANT TO GO!" Twitter. Available: https://twitter.com/realDonaldTrump/status/1241935285916782593

United States Department of Labor (2020). Office of Unemployment. "Insurance Weekly Claims Report. April 10, 2020. Available: https://www.dol.gov/ui/data.pdf 
Figure 1. Time trends in New Unemployment Insurance Claims by COVID-19 Cases and School Closures.

Effects of COVID-19 Cases on Unemployment Insurance Claims

States by Number of COVID-19 Cases per 100,000 inhab. (21Mar2020)

$$
\text { - Low }(<1.5) \quad-\text { Medium (1.5-3) }- \text { High }(>3)
$$

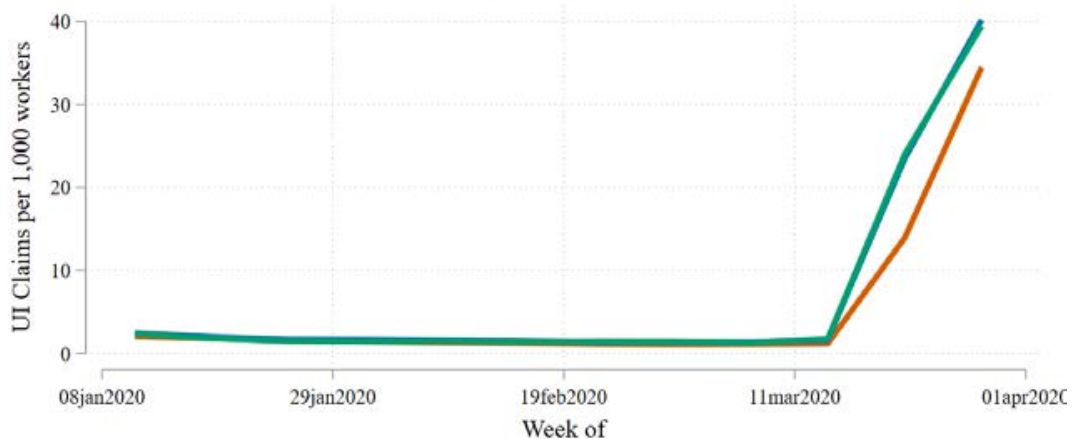

States according to their number of cases per capita

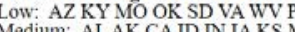

Medium A AL AK CA ID IN IA KS MD MN MT NE NM NC OH OR PA SC TX
Higl: AR CO CT DE DC FL GA HI LL LA ME MA MI MS NV NH NJ NY ND RI TN UT VT WA WI WY
Effects of School Closures on Unemployment Insurance Claims
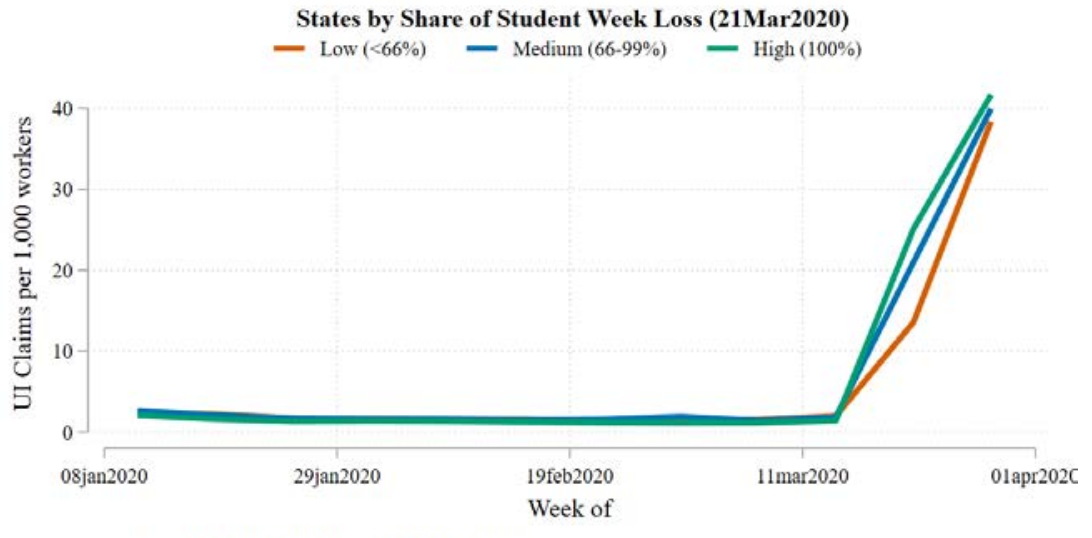

States according to their share or student week loss

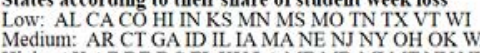

Medium: AR CT GA ID IL IA MA NE NJ NY OH OK WA
High: AK AZ DE DC FL KY LA ME MD MI MT NV NH NM NC ND OR PA RI SC SD UT VA WV WY PR

Panel A and Panel B of Figure 1 show time trends in new Unemployment Insurance (UI) claims grouped by state COVID-19 infection rates and school closures. The horizontal axis shows weeks since January 1st, 2020, and the vertical axis is the log number of unemployment

insurance claims per 1,000 workers. Each panel reports time trends for three groups. In Panel A, states are divided into those with a low, medium, or high number of COVID-19 cases per capita as of March 215t. Panel B splits the states into low, medium, and high groups based on the share of school time students lost during the corresponding week due to school closures as of March 21 ${ }^{\text {st }}$. The time trends, in both panels, spike in correspondence of the fourth week of March (22-28 March). The steepness of the spike appears sharpest for states with the earliest school closure and highest per capita COVID-19 cases. 
Figure 2
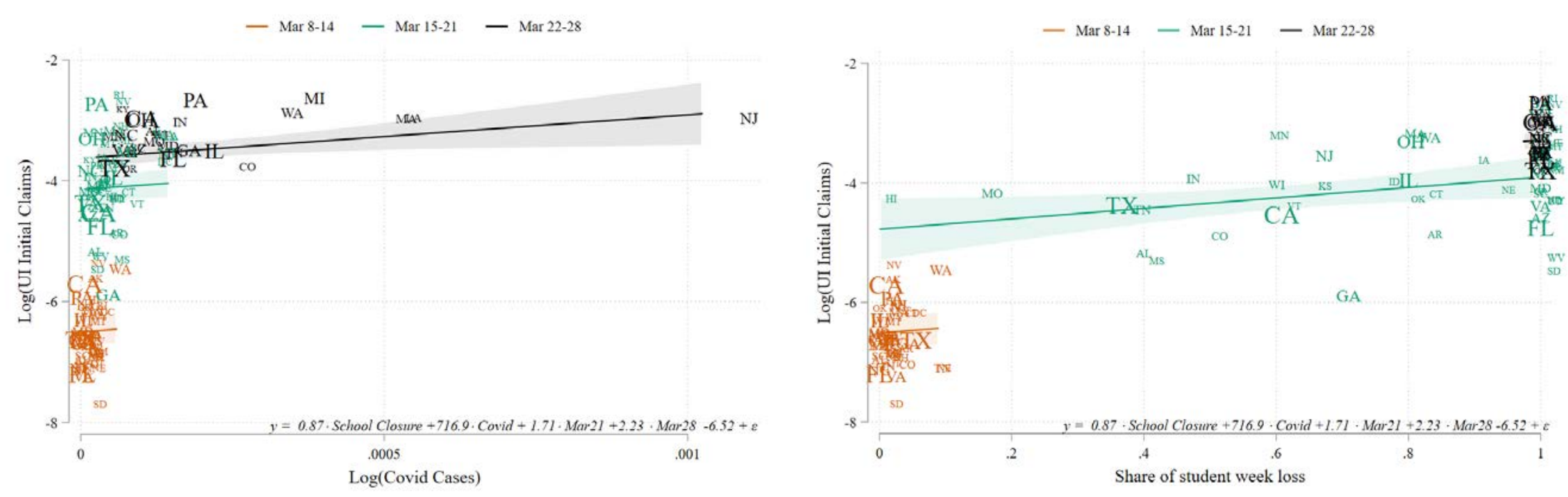

Panel A shows the relationship between the weekly per capita COVID-19 cases in each state on the horizontal axis and log of new unemployment insurance claims that week per 1,000 workers on the vertical axis. Panel B shows the relationship between the school days in a week missed per student due to school closure in the state on the horizontal axis and log of new unemployment insurance claims that week per 1,000 workers on the vertical axis. We report data for March 7-14 in orange, March 15-21 in green and March 22-28 in black. Solid lines show fitted estimates from a regression that includes a dummy variable for the week of March 15-21, a separate dummy variable for the week of March 22-28, per capita

COVID-19 cases in each week, and the share of school days lost (Table 2 Model (8)). State labels are sized in proportion to their 2019 population. The shaded area corresponds to the 95\% confidence interval calculated from standard errors clustered at the state level. 
Table 1. Descriptive Statistics.

\begin{tabular}{llcc} 
& & Mean & Std. Dev. \\
\hline March 8-14 & & & \\
& New UI Claims & 4,834 & 8,485 \\
& UI Claims / 1,000 Workers & 0.0017 & 0.0009 \\
& COVID-19 Cases/Population & 0.7448 & 1.104 \\
& Ln(UI Claims / Worker) & -6.4947 & 0.4991 \\
& Ln(1+COVID-19 Cases/Population) & 0.000007 & 0.000011 \\
& Share of student week lost & $1.85 \%$ & $2.43 \%$ \\
& Population & $6,374,889$ & $7,302,085$ \\
\hline March 15-21 & & \\
& New UI Claims & 56,155 & 67,624 \\
& UI Claims / 1,000 Workers & 0.0198 & 0.0150 \\
& COVID-19 Cases/Population & 6.5202 & 11.432 \\
& Ln(UI Claims / Worker) & -4.1571 & 0.6896 \\
& Ln(1+COVID-19 Cases/Population) & 0.000065 & 0.000114 \\
& Share of student week lost & $75.3 \%$ & $23.9 \%$ \\
& Population & $6,374,889$ & $7,302,085$ \\
\hline & & \\
& New UI Claims & 111,995 & 144,448 \\
& UI Claims / 1,000 Workers & 0.0400 & 0.0143 \\
& COVID-19 Cases/Population & 29.8738 & 51.789 \\
Ln(UI Claims / Worker) & -3.2815 & 0.3591 \\
Ln(1+COVID-19 Cases/Population) & 0.000299 & 0.000517 \\
Population & $100.0 \%$ & $0.3 \%$ \\
Share of student days lost & $6,374,889$ & $7,302,085$ \\
\hline N & 156 & \\
\hline
\end{tabular}

Note: COVID-19 Cases/Population is expressed per 100,000 individuals 
Table 2. Relationship between state labor markets, school closures, COVID-19 cases, and time (population weighted - excluding New York)

\begin{tabular}{|c|c|c|c|c|c|c|c|c|c|c|}
\hline & \multirow{3}{*}{$\begin{array}{c}(1) \\
\text { Time Effect } \\
\text { Log(UI } \\
\text { init. ,claims) }\end{array}$} & $(2)$ & (3) & $(4)$ & $(5)$ & $(6)$ & $(7)$ & $(8)$ & $(9)$ & $(10)$ \\
\hline & & & hool Closu & & & VID-19 Cas & & School Clo & ures + COV & D-19 Cases \\
\hline & & $\begin{array}{l}\log (\text { UI init. } \\
\text { claims })\end{array}$ & $\begin{array}{l}\text { Log(UI init. } \\
\text { claims) }\end{array}$ & $\begin{array}{l}\log (\text { UI init. } \\
\text { claims })\end{array}$ & $\begin{array}{l}\log (\mathrm{UI} \text { init. } \\
\text { claims })\end{array}$ & $\begin{array}{l}\log (\text { UI init. } \\
\text { claims })\end{array}$ & $\begin{array}{l}\text { Log(UI init. } \\
\text { claims) }\end{array}$ & $\begin{array}{l}\log (\text { UI init. } \\
\text { claims })\end{array}$ & $\begin{array}{l}\text { Log(UI init. } \\
\text { claims })\end{array}$ & $\begin{array}{l}\log (\text { UI init. } \\
\text { claims) }\end{array}$ \\
\hline Mar 21 & $\begin{array}{l}2.376^{\star \star \star} \\
(0.182)\end{array}$ & $\begin{array}{l}1.726^{\star \star \star} \\
(0.344)\end{array}$ & $\begin{array}{l}1.744^{\star \star \star} \\
(0.389)\end{array}$ & $\begin{array}{l}1.803^{\star \star \star} \\
(0.516)\end{array}$ & $\begin{array}{l}2.352^{\star \star \star} \\
(0.180)\end{array}$ & $\begin{array}{l}2.294^{\star \star \star} \\
(0.202)\end{array}$ & $\begin{array}{l}2.335^{\star \star \star} \\
(0.231)\end{array}$ & $\begin{array}{l}1.712^{\star \star \star} \\
(0.344)\end{array}$ & $\begin{array}{l}1.676^{\star \star \star} \\
(0.377)\end{array}$ & $\begin{array}{l}1.736^{\star \star \star} \\
(0.555)\end{array}$ \\
\hline Mar 28 & $\begin{array}{l}3.211^{\star \star \star} \\
(0.0957)\end{array}$ & $\begin{array}{l}2.341^{\star \star *} \\
(0.410)\end{array}$ & $\begin{array}{c}3.682 \\
(3.183)\end{array}$ & $\begin{array}{l}-3.296 \\
(2.964)\end{array}$ & $\begin{array}{l}3.083^{\star \star \star} \\
(0.0995)\end{array}$ & $\begin{array}{l}3.239^{\star \star \star} \\
(0.0946)\end{array}$ & $\begin{array}{l}3.272^{\star \star \star} \\
(0.114)\end{array}$ & $\begin{array}{l}2.229^{* \star *} \\
(0.406)\end{array}$ & $\begin{array}{c}5.934 \\
(3.648)\end{array}$ & $\begin{array}{l}-3.551 \\
(3.364)\end{array}$ \\
\hline Student week loss & & $\begin{array}{l}0.887^{\star \star} \\
(0.391)\end{array}$ & $\begin{array}{c}1.577 \\
(4.264)\end{array}$ & $\begin{array}{c}2.837 \\
(3.268)\end{array}$ & & & & $\begin{array}{l}0.875^{\star \star} \\
(0.392)\end{array}$ & $\begin{array}{l}-3.069 \\
(2.982)\end{array}$ & $\begin{array}{c}1.171 \\
(4.301)\end{array}$ \\
\hline $\begin{array}{l}\text { Mar } 21 \times \text { Student } \\
\text { week loss }\end{array}$ & & & $\begin{array}{l}-0.697 \\
(4.358)\end{array}$ & $\begin{array}{l}-2.005 \\
(3.521)\end{array}$ & & & & & $\begin{array}{c}3.879 \\
(3.175)\end{array}$ & $\begin{array}{l}-0.320 \\
(4.641)\end{array}$ \\
\hline $\begin{array}{l}\text { Mar } 28 \times \text { Student } \\
\text { week loss }\end{array}$ & & & $\begin{array}{l}-2.018 \\
(5.151)\end{array}$ & $\begin{array}{c}3.725 \\
(2.839)\end{array}$ & & & & & $\begin{array}{c}0.338 \\
(5.857)\end{array}$ & $\begin{array}{c}5.669 \\
(3.893)\end{array}$ \\
\hline Log(COVID-19 cases) & & & & & $\begin{array}{l}739.9^{\star \star} \\
(333.4)\end{array}$ & $\begin{array}{c}20304.8^{\star \star \star} \\
(3567.5)\end{array}$ & $\begin{array}{l}11720.8^{\star \star} \\
(4561.6)\end{array}$ & $\begin{array}{l}716.9^{* \star} \\
(311.7)\end{array}$ & $\begin{array}{c}23894.6^{\star \star \star} \\
(4721.5)\end{array}$ & $\begin{array}{l}10300.2 \\
(8162.0)\end{array}$ \\
\hline $\begin{array}{l}\text { Mar } 21 \times \\
\text { Log(COVID-19 cases })\end{array}$ & & & & & & $\begin{array}{l}-14810^{\star \star \star} \\
(4098.0)\end{array}$ & $\begin{array}{l}-8721.4^{\star \star} \\
(3622.1)\end{array}$ & & $\begin{array}{l}-19072^{\star \star \star} \\
(5032.1)\end{array}$ & $\begin{array}{l}-8056.9 \\
(6959.2)\end{array}$ \\
\hline $\begin{array}{l}\text { Mar } 28 \times \\
\quad \log (\text { COVID-19 cases }) \\
\end{array}$ & & & & & & $\begin{array}{l}-19751^{\star \star \star} \\
(3607.7) \\
\end{array}$ & $\begin{array}{c}-11653.0^{* *} \\
(4379.4) \\
\end{array}$ & & $\begin{array}{l}-23339^{\star \star \star} \\
(4839.4)\end{array}$ & $\begin{array}{l}-10247.8 \\
(8032.8) \\
\end{array}$ \\
\hline States' F.E. & & & & $x$ & & & $x$ & & & $x$ \\
\hline $\mathrm{N}$ & 153 & 153 & 153 & 153 & 153 & 153 & 153 & 153 & 153 & 153 \\
\hline Adj. R2 & 0.863 & 0.870 & 0.868 & 0.925 & 0.866 & 0.874 & 0.919 & 0.872 & 0.879 & 0.924 \\
\hline $\mathrm{R} 2$ & 0.865 & 0.873 & 0.873 & 0.952 & 0.868 & 0.878 & 0.948 & 0.876 & 0.885 & 0.953 \\
\hline
\end{tabular}

Standard errors clustered at the state level in parentheses. UI initial claims expressed in per employed person and COVID-19 cases in per capita terms, both within each state. ${ }^{*} p<0.1{ }^{* *} p<$ $0.05, \quad p<0.01$ 
Is the Cure Worse than the Disease?

Short Term Labor Market Effects of COVID-19 Case Rates and School Closures in the U.S.

Xuan Jiang ${ }^{1}$, Felipe Lozano Rojas ${ }^{2}$, Laura Montenovo², Kosali Simon ${ }^{23}$, Bruce A. Weinberg ${ }^{134}$, Coady Wing $^{2}$

(Note: Equal contribution by all authors, who are listed alphabetically)

\section{Supplementary Materials}

${ }^{1}$ Ohio State University, Columbus, Ohio.

2 Indiana University, Bloomington, Indiana.

${ }^{3}$ National Bureau of Economic Research, Cambridge, Massachusetts.

${ }^{4}$ IZA Institute for the Study of Labor, Bonn, Germany. 
Figure S.1

- Mar 8-14 - Mar 15-21 - Mar 22-28

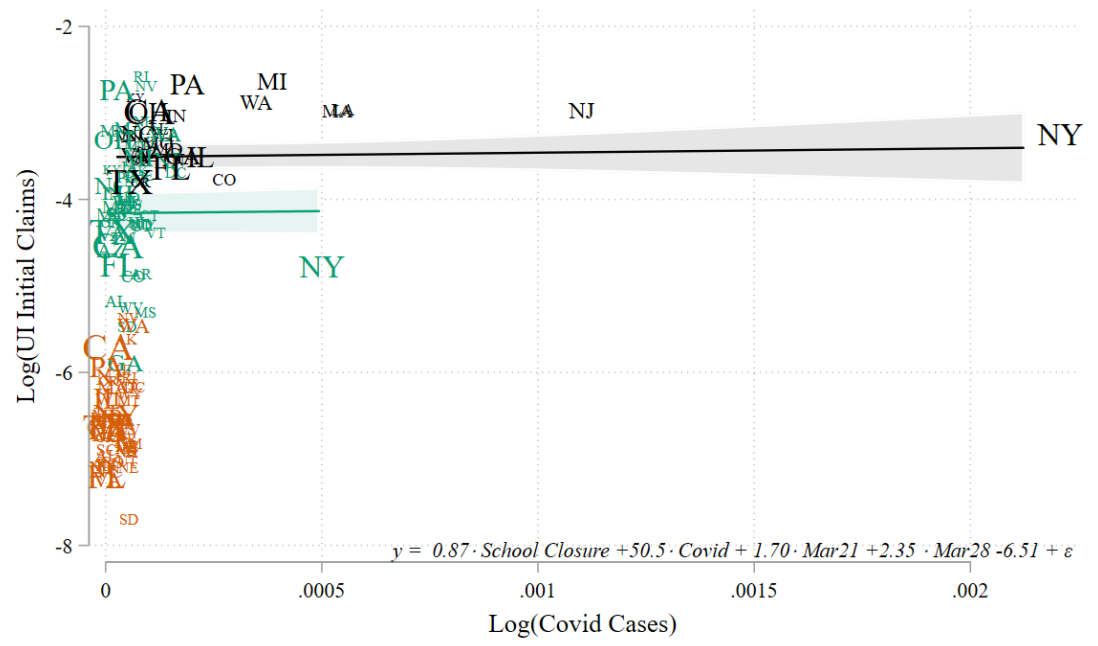

- Mar 8-14 - Mar 15-21 - Mar 22-28

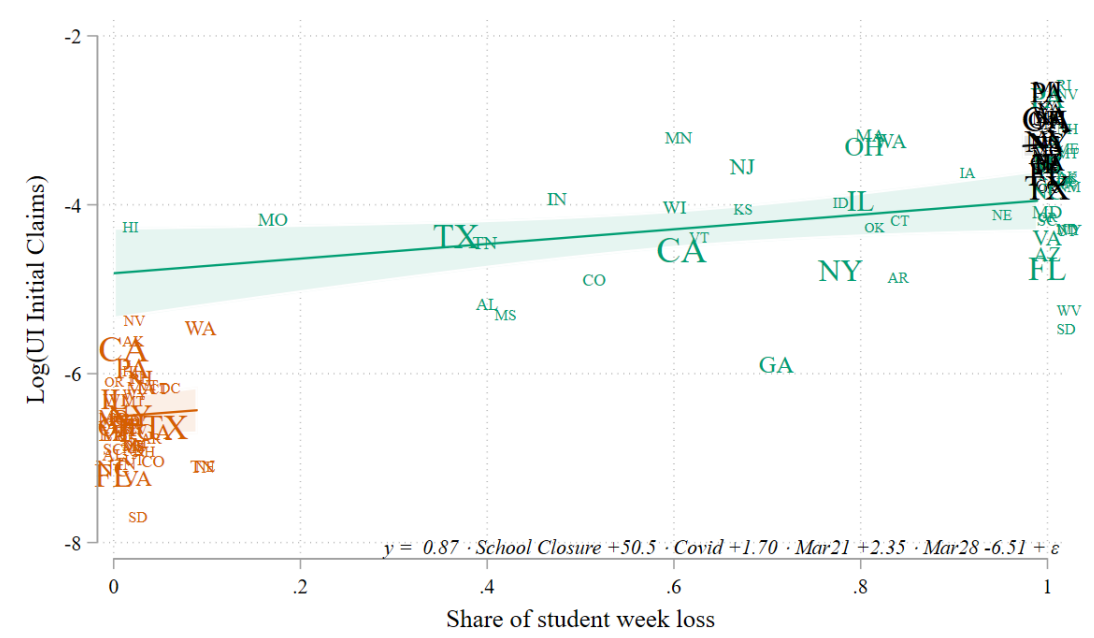

Panel A shows the relationship between the weekly per capita COVID-19 cases in each state on the horizontal axis and log of new unemployment insurance claims that week per 1,000 workers on the vertical axis. Panel B shows the relationship between the school days in a week missed per student due to school closure in the state on the horizontal axis and log of new unemployment insurance claims that week per 1,000 workers on the vertical axis. We report data for March 7-14 in orange, March 15-21 in green and March 22-28 in black. Solid lines show fitted estimates from a regression that includes a dummy variable for the week of March 15-21, a separate dummy variable for the week of March 22-28, per capita COVID-19 cases in each week, and the share of school days lost (Table S.1 Model (8)). State labels are sized in proportion to their 2019 population. The shaded area corresponds to the $95 \%$ confidence interval calculated from standard errors clustered at the state level. 
Table S.1. Relationship between state labor markets, school closures COVID-19 cases and time (weighted - including New York

\begin{tabular}{|c|c|c|c|c|c|c|c|c|c|c|}
\hline & \multirow{2}{*}{$\frac{(1)}{\text { Time Effect }}$} & $(2)$ & $(3)$ & $(4)$ & (5) & (6) & (7) & $(8)$ & (9) & $(10)$ \\
\hline & & \multicolumn{3}{|c|}{ School Closures } & \multicolumn{3}{|c|}{ COVID-19 Cases } & \multicolumn{3}{|c|}{ School Closures + COVID-19 Cases } \\
\hline & $\begin{array}{l}\text { Log(Ul init. } \\
\text { claims) }\end{array}$ & $\begin{array}{l}\text { Log(Ul init. } \\
\text { claims })\end{array}$ & $\begin{array}{l}\text { Log(UI init. } \\
\text { claims })\end{array}$ & $\begin{array}{l}\text { Log(UI init. } \\
\text { claims })\end{array}$ & $\begin{array}{l}\text { Log(UI init. } \\
\text { claims })\end{array}$ & $\begin{array}{l}\text { Log }(\mathrm{UI} \text { init. } \\
\text { claims })\end{array}$ & $\begin{array}{l}\text { Log(UI init. } \\
\text { claims })\end{array}$ & $\begin{array}{l}\text { Log(UI init. } \\
\text { claims })\end{array}$ & $\begin{array}{l}\text { Log(UI init. } \\
\text { claims })\end{array}$ & $\begin{array}{l}\text { Log(UI init. } \\
\text { claims })\end{array}$ \\
\hline Mar 21 & $\begin{array}{l}2.338^{\star \star *} \\
(0.172)\end{array}$ & $\begin{array}{l}1.699^{\star \star \star} \\
(0.337)\end{array}$ & $\begin{array}{l}1.717^{\star \star \star} \\
(0.377)\end{array}$ & $\begin{array}{l}1.778^{\star \star \star} \\
(0.509)\end{array}$ & $\begin{array}{l}2.334^{\star \star \star} \\
(0.171)\end{array}$ & $\begin{array}{l}2.516^{\star \star *} \\
(0.190)\end{array}$ & $\begin{array}{l}2.451^{* \star *} \\
(0.198)\end{array}$ & $\begin{array}{l}1.697^{* * *} \\
(0.336)\end{array}$ & $\begin{array}{l}1.832^{\star * \star} \\
(0.378)\end{array}$ & $\begin{array}{l}1.802^{* \star *} \\
(0.532)\end{array}$ \\
\hline Mar 28 & $\begin{array}{l}3.213^{* * \star} \\
(0.0903)\end{array}$ & $\begin{array}{l}2.360^{* * *} \\
(0.403)\end{array}$ & $\begin{array}{c}3.583 \\
(2.997)\end{array}$ & $\begin{array}{l}-4.183 \\
(2.941)\end{array}$ & $\begin{array}{c}3.197^{* * \star} \\
(0.0945)\end{array}$ & $\begin{array}{l}3.308^{* * *} \\
(0.0983)\end{array}$ & $\begin{array}{l}3.251^{* * *} \\
(0.106)\end{array}$ & $\begin{array}{l}2.347^{* * *} \\
(0.397)\end{array}$ & $\begin{array}{c}4.436 \\
(3.421)\end{array}$ & $\begin{array}{l}-2.160 \\
(3.378)\end{array}$ \\
\hline Student week loss & & $\begin{array}{l}0.869^{* *} \\
(0.390)\end{array}$ & $\begin{array}{c}1.576 \\
(4.262)\end{array}$ & $\begin{array}{c}2.860 \\
(3.243)\end{array}$ & & & & $\begin{array}{l}0.868^{\star *} \\
(0.392)\end{array}$ & $\begin{array}{l}-1.955 \\
(2.830)\end{array}$ & $\begin{array}{c}1.112 \\
(4.347)\end{array}$ \\
\hline $\begin{array}{l}\text { Mar } 21 \times \text { Student } \\
\text { week loss }\end{array}$ & & & $\begin{array}{l}-0.714 \\
(4.339)\end{array}$ & $\begin{array}{l}-2.047 \\
(3.484)\end{array}$ & & & & & $\begin{array}{c}2.843 \\
(2.990)\end{array}$ & $\begin{array}{l}-0.219 \\
(4.686)\end{array}$ \\
\hline $\begin{array}{l}\text { Mar } 28 \times \text { Student } \\
\text { week loss }\end{array}$ & & & $\begin{array}{l}-1.917 \\
(5.042)\end{array}$ & $\begin{array}{c}4.590 \\
(2.809)\end{array}$ & & & & & $\begin{array}{c}0.805 \\
(5.146)\end{array}$ & $\begin{array}{c}4.317 \\
(3.507)\end{array}$ \\
\hline Log(COVID-19 cases) & & & & & $\begin{array}{c}55.77 \\
(108.7)\end{array}$ & $\begin{array}{c}16446.3^{* \star \star} \\
(4003.5)\end{array}$ & $\begin{array}{l}8373.5^{\star *} \\
(3773.4)\end{array}$ & $\begin{array}{c}50.49 \\
(106.7)\end{array}$ & $\begin{array}{l}18276.6^{\star * \star} \\
(5191.8)\end{array}$ & $\begin{array}{c}7611.5 \\
(7564.0)\end{array}$ \\
\hline $\begin{array}{l}\text { Mar } 21 \times \\
\log (\text { COVID-19 cases })\end{array}$ & & & & & & $\begin{array}{l}-17308^{* \star *} \\
(3576.0)\end{array}$ & $\begin{array}{l}-9164.4^{* *} \\
(3538.8)\end{array}$ & & $\begin{array}{l}-19242^{* * *} \\
(4763.1)\end{array}$ & $\begin{array}{l}-8534.5 \\
(7037.8)\end{array}$ \\
\hline $\begin{array}{l}\text { Mar } 28 \times \\
\text { Log(COVID-19 cases })\end{array}$ & & & & & & $\begin{array}{l}-16353^{* \star *} \\
(3947.5)\end{array}$ & $\begin{array}{l}-8291^{\star \star} \\
(3730.5)\end{array}$ & & $\begin{array}{l}-18183^{* * *} \\
(5150.3)\end{array}$ & $\begin{array}{l}-7536.3 \\
(7469.5)\end{array}$ \\
\hline States' F.E. & & & & $\mathrm{X}$ & & & $\mathrm{X}$ & & & $\mathrm{X}$ \\
\hline$\overline{\mathrm{N}}$ & 156 & 156 & 156 & 156 & 156 & 156 & 156 & 156 & 156 & 156 \\
\hline Adj. R2 & 0.867 & 0.873 & 0.871 & 0.925 & 0.866 & 0.871 & 0.921 & 0.872 & 0.876 & 0.926 \\
\hline $\mathrm{R} 2$ & 0.868 & 0.875 & 0.875 & 0.952 & 0.868 & 0.875 & 0.949 & 0.875 & 0.882 & 0.954 \\
\hline
\end{tabular}

Standard errors clustered at the state level in parentheses. UI initial claims expressed in per employed person and COVID-19 cases in per capita terms, both within each state. ${ }^{*} p<0.1,{ }^{* *} p<$ $0.05, \quad p<0.01$ 
Table S.2. Relationship between state labor markets, school closures COVID-19 cases and time (unweighted - excluding New York)

\begin{tabular}{|c|c|c|c|c|c|c|c|c|c|c|}
\hline & \multirow{2}{*}{$\frac{(1)}{\text { Time Effect }}$} & $(2)$ & $(3)$ & $(4)$ & $(5)$ & $(6)$ & $(7)$ & $(8)$ & $(9)$ & $(10)$ \\
\hline & & \multicolumn{3}{|c|}{ School Closures } & \multicolumn{3}{|c|}{ COVID-19 Cases } & \multicolumn{3}{|c|}{ School Closures + COVID-19 Cases } \\
\hline & $\begin{array}{l}\log (U l \text { init. } \\
\text { claims })\end{array}$ & $\begin{array}{l}\log (U \mathrm{U} \text { init. } \\
\text { claims })\end{array}$ & $\begin{array}{l}\text { Log(UI init. } \\
\text { claims })\end{array}$ & $\begin{array}{l}\text { Log(UI init. } \\
\text { claims) }\end{array}$ & $\begin{array}{l}\text { Log(UI init. } \\
\text { claims) }\end{array}$ & $\begin{array}{l}\log (U \mathrm{U} \text { init. } \\
\text { claims })\end{array}$ & $\begin{array}{l}\text { Log(Ul init. } \\
\text { claims })\end{array}$ & $\begin{array}{l}\log (\text { Ul init. } \\
\text { claims })\end{array}$ & $\begin{array}{l}\text { Log(UI init. } \\
\text { claims) }\end{array}$ & $\begin{array}{l}\log (\mathrm{UI} \text { init. } \\
\text { claims })\end{array}$ \\
\hline Mar 21 & $\begin{array}{l}2.529^{* * *} \\
(0.0906)\end{array}$ & $\begin{array}{l}1.822^{\star \star \star} \\
(0.276)\end{array}$ & $\begin{array}{l}1.821^{\star \star \star} \\
(0.289)\end{array}$ & $\begin{array}{l}1.756^{\star \star \star} \\
(0.232)\end{array}$ & $\begin{array}{l}2.505^{\star \star *} \\
(0.0912)\end{array}$ & $\begin{array}{l}2.420^{\star * *} \\
(0.121)\end{array}$ & $\begin{array}{l}2.483^{\star * \star} \\
(0.118)\end{array}$ & $\begin{array}{l}1.802^{* * *} \\
(0.278)\end{array}$ & $\begin{array}{l}1.694^{* * *} \\
(0.298)\end{array}$ & $\begin{array}{l}1.674^{\star \star \star} \\
(0.250)\end{array}$ \\
\hline Mar 28 & $\begin{array}{l}3.238^{\star * *} \\
(0.0642)\end{array}$ & $\begin{array}{l}2.367^{* * *} \\
(0.333)\end{array}$ & $\begin{array}{l}4.716^{* *} \\
(2.141)\end{array}$ & $\begin{array}{l}-1.673 \\
(2.058)\end{array}$ & $\begin{array}{l}3.118^{* * *} \\
(0.0794)\end{array}$ & $\begin{array}{l}3.264^{* * *} \\
(0.0709)\end{array}$ & $\begin{array}{l}3.307^{\star \star *} \\
(0.0748)\end{array}$ & $\begin{array}{l}2.252^{* * *} \\
(0.337)\end{array}$ & $\begin{array}{l}6.705^{* * *} \\
(2.322)\end{array}$ & $\begin{array}{l}-2.904 \\
(2.195)\end{array}$ \\
\hline Student week loss & & $\begin{array}{l}0.884^{* *} \\
(0.333)\end{array}$ & $\begin{array}{c}0.811 \\
(4.123)\end{array}$ & $\begin{array}{c}1.851 \\
(2.732)\end{array}$ & & & & $\begin{array}{l}0.880^{* *} \\
(0.334)\end{array}$ & $\begin{array}{l}-4.499^{*} \\
(2.305)\end{array}$ & $\begin{array}{c}0.151 \\
(3.174)\end{array}$ \\
\hline $\begin{array}{l}\text { Mar } 21 \times \text { Student } \\
\text { week loss }\end{array}$ & & & $\begin{array}{l}0.0748 \\
(4.146)\end{array}$ & $\begin{array}{l}-0.868 \\
(2.725)\end{array}$ & & & & & $\begin{array}{l}5.368^{\star *} \\
(2.376)\end{array}$ & $\begin{array}{c}0.858 \\
(3.201)\end{array}$ \\
\hline $\begin{array}{l}\text { Mar } 28 \times \text { Student } \\
\text { week loss }\end{array}$ & & & $\begin{array}{l}-2.278 \\
(4.485)\end{array}$ & $\begin{array}{c}3.089 \\
(2.873)\end{array}$ & & & & & $\begin{array}{c}1.030 \\
(3.669)\end{array}$ & $\begin{array}{l}6.076^{*} \\
(3.053)\end{array}$ \\
\hline Log(COVID-19 cases) & & & & & $\begin{array}{l}725.5^{\star *} \\
(301.2)\end{array}$ & $\begin{array}{l}17555.0^{\star \star \star} \\
(2919.0)\end{array}$ & $\begin{array}{l}9043.5^{* *} \\
(4131.1)\end{array}$ & $\begin{array}{l}715.5^{\star *} \\
(292.8)\end{array}$ & $\begin{array}{c}23533.8^{* \star *} \\
(4382.0)\end{array}$ & $\begin{array}{c}9651.4 \\
(5907.1)\end{array}$ \\
\hline $\begin{array}{l}\text { Mar } 21 \times \\
\quad \log (\text { COVID-19 cases })\end{array}$ & & & & & & $\begin{array}{l}-11915^{* * *} \\
(3209.9)\end{array}$ & $\begin{array}{l}-6396.7^{*} \\
(3511.6)\end{array}$ & & $\begin{array}{l}-18040^{* * *} \\
(4830.6)\end{array}$ & $\begin{array}{l}-7146.4 \\
(5662.6)\end{array}$ \\
\hline $\begin{array}{l}\text { Mar } 28 \times \\
\quad \text { Log(COVID-19 cases })\end{array}$ & & & & & & $\begin{array}{l}-17053^{\star \star \star} \\
(2915.6)\end{array}$ & $\begin{array}{l}-9107.3^{* *} \\
(3981.4)\end{array}$ & & $\begin{array}{l}-23026^{\star * *} \\
(4400.1)\end{array}$ & $\begin{array}{l}-9753.3 \\
(5844.7)\end{array}$ \\
\hline States' F.E. & & & & $\mathrm{X}$ & & & $\mathrm{X}$ & & & $\mathrm{X}$ \\
\hline$\overline{\mathrm{N}}$ & 153 & 153 & 153 & 153 & 153 & 153 & 153 & 153 & 153 & 153 \\
\hline Adj. R2 & 0.869 & 0.875 & 0.874 & 0.938 & 0.871 & 0.877 & 0.930 & 0.877 & 0.883 & 0.938 \\
\hline $\mathrm{R} 2$ & 0.871 & 0.878 & 0.878 & 0.961 & 0.873 & 0.881 & 0.955 & 0.880 & 0.889 & 0.962 \\
\hline
\end{tabular}

Standard errors clustered at the state level in parentheses. UI initial claims expressed in per employed person and COVID-19 cases in per capita terms, both within each state. ${ }^{*} p<0.1,{ }^{* *} p<$ $0.05, \quad p<0.01$ 
Table S.3. Relationship between state labor markets, school closures COVID-19 cases and time (unweighted - including New York)

\begin{tabular}{|c|c|c|c|c|c|c|c|c|c|c|}
\hline & \multirow{2}{*}{$\frac{(1)}{\text { Time Effect }}$} & $(2)$ & $(3)$ & $(4)$ & $(5)$ & $(6)$ & $(7)$ & $(8)$ & $(9)$ & $(10)$ \\
\hline & & \multicolumn{3}{|c|}{ School Closures } & \multicolumn{3}{|c|}{ COVID-19 Cases } & \multicolumn{3}{|c|}{ School Closures + COVID-19 Cases } \\
\hline & $\begin{array}{l}\text { Log(UI init. } \\
\text { claims) }\end{array}$ & $\begin{array}{l}\log (\text { UI init. } \\
\text { claims })\end{array}$ & $\begin{array}{l}\log (U \mathrm{I} \text { init. } \\
\text { claims })\end{array}$ & $\begin{array}{l}\log (U I \text { init. } \\
\text { claims })\end{array}$ & $\begin{array}{l}\text { Log(UI init. } \\
\text { claims) }\end{array}$ & $\begin{array}{l}\log (\text { UI init. } \\
\text { claims })\end{array}$ & $\begin{array}{l}\log (U \mathrm{U} \text { init. } \\
\text { claims })\end{array}$ & $\begin{array}{l}\log (\text { Ul init. } \\
\text { claims) }\end{array}$ & $\begin{array}{l}\log (\text { UI init. } \\
\text { claims })\end{array}$ & $\begin{array}{l}\log (\mathrm{UI} \text { init. } \\
\text { claims })\end{array}$ \\
\hline Mar 21 & $\begin{array}{l}2.514^{* \star *} \\
(0.0902)\end{array}$ & $\begin{array}{l}1.802^{\star \star \star} \\
(0.277)\end{array}$ & $\begin{array}{l}1.800^{* * *} \\
(0.290)\end{array}$ & $\begin{array}{l}1.735^{* \star *} \\
(0.232)\end{array}$ & $\begin{array}{l}2.507^{\star \star \star} \\
(0.0901)\end{array}$ & $\begin{array}{l}2.630^{* * *} \\
(0.114)\end{array}$ & $\begin{array}{l}2.591^{* * *} \\
(0.106)\end{array}$ & $\begin{array}{l}1.795^{\text {** }} \\
(0.278)\end{array}$ & $\begin{array}{l}1.880^{* * *} \\
(0.287)\end{array}$ & $\begin{array}{l}1.768^{\star \star \star} \\
(0.234)\end{array}$ \\
\hline Mar 28 & $\begin{array}{l}3.238^{* \star *} \\
(0.0630)\end{array}$ & $\begin{array}{l}2.359^{* * *} \\
(0.334)\end{array}$ & $\begin{array}{l}4.659^{* *} \\
(2.102)\end{array}$ & $\begin{array}{l}-1.966 \\
(2.046)\end{array}$ & $\begin{array}{l}3.204^{* * *} \\
(0.0724)\end{array}$ & $\begin{array}{l}3.315^{* \star *} \\
(0.0710)\end{array}$ & $\begin{array}{l}3.277^{\star \star *} \\
(0.0721)\end{array}$ & $\begin{array}{l}2.325^{* * *} \\
(0.335)\end{array}$ & $\begin{array}{l}5.614^{\star *} \\
(2.244)\end{array}$ & $\begin{array}{l}-1.214 \\
(2.251)\end{array}$ \\
\hline Student week loss & & $\begin{array}{l}0.892^{* *} \\
(0.335)\end{array}$ & $\begin{array}{c}0.820 \\
(4.117)\end{array}$ & $\begin{array}{c}1.896 \\
(2.743)\end{array}$ & & & & $\begin{array}{l}0.892^{* *} \\
(0.336)\end{array}$ & $\begin{array}{l}-4.082^{*} \\
(2.292)\end{array}$ & $\begin{array}{l}0.0854 \\
(3.132)\end{array}$ \\
\hline $\begin{array}{l}\text { Mar } 21 \times \text { Student } \\
\text { week loss }\end{array}$ & & & $\begin{array}{l}0.0733 \\
(4.138)\end{array}$ & $\begin{array}{l}-0.905 \\
(2.735)\end{array}$ & & & & & $\begin{array}{l}4.975^{\star *} \\
(2.346)\end{array}$ & $\begin{array}{c}0.932 \\
(3.141)\end{array}$ \\
\hline $\begin{array}{l}\text { Mar } 28 \times \text { Student } \\
\text { week loss }\end{array}$ & & & $\begin{array}{l}-2.230 \\
(4.469)\end{array}$ & $\begin{array}{c}3.337 \\
(2.861)\end{array}$ & & & & & $\begin{array}{c}1.757 \\
(3.513)\end{array}$ & $\begin{array}{c}4.416 \\
(3.011)\end{array}$ \\
\hline Log(COVID-19 cases) & & & & & $\begin{array}{c}167.8 \\
(177.8)\end{array}$ & $\begin{array}{c}16414.4^{* \star *} \\
(3235.5)\end{array}$ & $\begin{array}{c}6092.2 \\
(3821.2)\end{array}$ & $\begin{array}{c}167.2 \\
(176.4)\end{array}$ & $\begin{array}{c}21467.4^{\star \star \star} \\
(4657.6)\end{array}$ & $\begin{array}{c}7017.6 \\
(5942.5)\end{array}$ \\
\hline $\begin{array}{l}\text { Mar } 21 \times \\
\text { Log(COVID-19 cases })\end{array}$ & & & & & & $\begin{array}{l}-16510^{\star \star \star} \\
(3016.4)\end{array}$ & $\begin{array}{l}-6832.6^{*} \\
(3626.3)\end{array}$ & & $\begin{array}{l}-21542^{* \star *} \\
(4404.4)\end{array}$ & $\begin{array}{l}-7697.0 \\
(5763.0)\end{array}$ \\
\hline $\begin{array}{l}\text { Mar } 28 \times \\
\text { Log(COVID-19 cases })\end{array}$ & & & & & & $\begin{array}{l}-16249^{* \star *} \\
(3199.8) \\
\end{array}$ & $\begin{array}{l}-6082.8 \\
(3778.0) \\
\end{array}$ & & $\begin{array}{l}-21300^{* * *} \\
(4626.9) \\
\end{array}$ & $\begin{array}{l}-7011.7 \\
(5895.4) \\
\end{array}$ \\
\hline States' F.E. & & & & $\mathrm{X}$ & & & $\mathrm{X}$ & & & $\mathrm{X}$ \\
\hline $\mathrm{N}$ & 156 & 156 & 156 & 156 & 156 & 156 & 156 & 156 & 156 & 156 \\
\hline Adj. R2 & 0.869 & 0.876 & 0.874 & 0.938 & 0.869 & 0.871 & 0.929 & 0.876 & 0.877 & 0.937 \\
\hline $\mathrm{R} 2$ & 0.871 & 0.878 & 0.878 & 0.960 & 0.872 & 0.875 & 0.955 & 0.879 & 0.884 & 0.961 \\
\hline
\end{tabular}

Standard errors clustered at the state level in parentheses. UI initial claims expressed in per employed person and COVID-19 cases in per capita terms, both within each state. ${ }^{*} p<0.1,{ }^{* *} p<$ $0.05, \quad p<0.01$ 
Table S.5. Individual state unemployment insurance claims and model residuals

\begin{tabular}{|c|c|c|c|c|c|c|c|c|c|}
\hline \multirow[b]{2}{*}{ State } & \multicolumn{3}{|c|}{ Initial Claims (DoL) } & \multirow{2}{*}{$\begin{array}{c}\text { Residuals } \\
\text { 28-Mar }\end{array}$} & \multirow[b]{2}{*}{ State } & \multicolumn{3}{|c|}{ Initial Claims (DoL) } & \multirow{2}{*}{$\begin{array}{c}\text { Residuals } \\
\text { 28-Mar }\end{array}$} \\
\hline & 14-Mar & 21-Mar & 28-Mar & & & 14-Mar & 21-Mar & 28-Mar & \\
\hline Hawaii & 1,589 & 8,817 & 48,861 & 0.81 & Missouri & 4,016 & 42,246 & 96,734 & -0.02 \\
\hline Pennsylvania & 15,439 & 377,451 & 405,880 & 0.62 & Maryland & 3,864 & 42,981 & 83,536 & -0.11 \\
\hline Kentucky & 2,785 & 49,023 & 112,726 & 0.54 & South Carolina & 2,093 & 31,826 & 64,856 & -0.12 \\
\hline Michigan & 5,338 & 128,006 & 311,086 & 0.51 & Virginia & 2,706 & 46,277 & 114,104 & -0.12 \\
\hline Rhode Island & 1,108 & 35,847 & 28,067 & 0.47 & Arizona & 3,844 & 29,348 & 89,064 & -0.12 \\
\hline Puerto Rico & 1,172 & 20,148 & 45,218 & 0.46 & North Dakota & 415 & 5,662 & 12,591 & -0.13 \\
\hline Ohio & 7,046 & 196,309 & 272,129 & 0.37 & Oklahoma & 1,836 & 21,926 & 44,970 & -0.19 \\
\hline California & 57,606 & 186,333 & 878,727 & 0.37 & Georgia & 5,445 & 12,140 & 132,386 & -0.21 \\
\hline Nevada & 6,356 & 92,298 & 71,419 & 0.33 & Tennessee & 2,702 & 38,077 & 94,492 & -0.24 \\
\hline Washington & 14,240 & 129,909 & 187,501 & 0.29 & Illinois & 10,870 & 114,114 & 178,133 & -0.25 \\
\hline Alaska & 1,120 & 7,847 & 14,523 & 0.28 & Nebraska & 795 & 15,700 & 24,572 & -0.28 \\
\hline Idaho & 1,031 & 13,586 & 32,240 & 0.28 & Mississippi & 1,147 & 5,519 & 30,946 & -0.29 \\
\hline Indiana & 2,596 & 59,755 & 146,243 & 0.26 & Florida & 6,463 & 74,313 & 227,000 & -0.33 \\
\hline Montana & 817 & 15,349 & 19,540 & 0.19 & New Jersey & 9,467 & 115,815 & 205,515 & -0.35 \\
\hline Vermont & 659 & 3,784 & 14,443 & 0.18 & Texas & 16,176 & 155,426 & 275,597 & -0.41 \\
\hline New Hampshire & 642 & 29,379 & 27,454 & 0.16 & Oregon & 4,269 & 30,054 & 42,502 & -0.45 \\
\hline Alabama & 1,819 & 10,892 & 80,186 & 0.15 & Arkansas & 1,382 & 9,275 & 26,944 & -0.45 \\
\hline Kansas & 1,755 & 23,563 & 54,739 & 0.15 & West Virginia & 865 & 3,536 & 14,166 & -0.48 \\
\hline Delaware & 472 & 10,776 & 18,987 & 0.14 & D.C. & 1,213 & 14,462 & 14,868 & -0.50 \\
\hline lowa & 2,229 & 40,952 & 58,453 & 0.13 & Colorado & 2,321 & 19,774 & 60,784 & -0.56 \\
\hline North Carolina & 3,533 & 94,083 & 170,881 & 0.12 & Utah & 1,305 & 19,690 & 28,560 & -0.62 \\
\hline Minnesota & 4,010 & 115,773 & 109,896 & 0.12 & Wyoming & 517 & 3,653 & 4,675 & -0.71 \\
\hline Maine & 634 & 21,459 & 23,535 & 0.10 & Connecticut & 3,440 & 25,100 & 33,182 & -0.76 \\
\hline Wisconsin & 5,190 & 51,031 & 110,724 & 0.07 & South Dakota & 190 & 1,761 & 6,645 & -0.77 \\
\hline Louisiana & 2,255 & 72,438 & 97,830 & 0.06 & & & & & \\
\hline Massachusetts & 7,449 & 148,452 & 181,062 & 0.05 & & & & & \\
\hline New Mexico & 869 & 18,105 & 28,182 & 0.02 & & & & & \\
\hline
\end{tabular}

The Residuals Unemployment Claims column indicates the deviation of observed unemployment insurance claims from the claims predicted in Column 8 of Table 2 for March $28^{\text {th }}$. States with positive residuals have higher claims than are predicted by the model. States with negative residuals have lower unemployment claims than predicted by the model. 